\title{
Between Terror and Taboo: Monumentalisation as the Matrix of History and Politics in Orhan Pamuk's The Black Book and Snow
}

\section{Rita Sakr}

To cite this article: Rita Sakr (2011) Between Terror and Taboo: Monumentalisation as the Matrix of History and Politics in Orhan Pamuk's The Black Book and Snow, British Journal of Middle Eastern Studies, 38:2, 227-247, DOI: 10.1080/13530194.2011.581821

To link to this article: https://doi.org/10.1080/13530194.2011.581821

曲 Published online: 14 Sep 2011.

Submit your article to this journal ๘

Џ Article views: 631

Q View related articles $\longleftarrow$ 


\title{
Between Terror and Taboo: Monumentalisation as the Matrix of History and Politics in Orhan Pamuk's The Black Book and Snow
}

\author{
RITA SAKR*
}

\begin{abstract}
This essay explores monumentalisation as an idea and a practice that function as the matrix of history and politics in Orhan Pamuk's novels The Black Book and Snow. I examine the politics of Pamuk's negotiation of 'monumentalisation' in the two novels through its different textual trajectories: the surreal image of the apocalyptic agency of Ataturk statues in Turkish space and history; the elliptical and marginal representation of a centrally significant event in a tabooed monumental space, as in the instances of a carnivalesque performance around an Ataturk statue and of Kurdish attacks against these statues; and the textual monumentalisation of Armenian architectural remains that bear the traces of past violence. The main argument and conclusion are that Pamuk's imaginative rendering of monumental space allows a rethinking of the significance of monumentalisation on theoretical and material levels specifically with respect to its relations to various manifestations of terror and taboo in twentieth-century Turkey.
\end{abstract}

The work of the Turkish novelist and Nobel Prize winner Orhan Pamuk negotiates Turkey's contested cultural and political spaces, the overdetermined texture of its history and cultural memory, and the controversial facets of its contemporary national and international geopolitical concerns. ${ }^{1}$ The main argument of this article is that, in Pamuk's novels The Black Book and Snow, Pamuk's imaginative rendering of monumental space allows a rethinking of monumentalisation on theoretical and material levels specifically as it contributes to the negotiation of various aspects of taboo and terror in twentieth-century Turkey. From this

\footnotetext{
*UCD James Joyce Research Centre, School of English, Drama and Film, University College Dublin, Belfield, Dublin 4, Ireland. E-mail: rsakr1@gmail.com

${ }^{1}$ I am appropriating Laclau and Mouffe's post-Marxist theorisation of the concept of 'overdetermination' which they formulate on the basis of Althusser's original argument that 'everything existing in the social is overdetermined'. This argument implies that, 'far from there being an essentialist totalization, or a no less essentialist separation among objects, the presence of some objects in the others prevents any of their identities from being fixed'. Ernesto Laclau and Chantal Mouffe, Hegemony and Socialist Strategy: Towards a Radical Democratic Politics (2nd edn) (London: Verso, 2001), pp. 97-134. From this perspective, 'over-determination' - the meaning rather than merely the specific terminology-serves here as an appropriate and malleable conceptual tool to approach the multilayered texture of Turkey's political and social history and the relationship of Ataturk and Ataturk statues to this history.
} 
perspective, I approach the representation of several monumental spaces and of other spaces that are textually rendered as monumental or counter-monumentalthrough repetition, erasure, or other modes of representation-in the two novels, including Ataturk statues and Armenian architectural remains.

My approach to monumental space and spaces that are textually monumentalised in Pamuk's novels evolves from Pierre Nora's fluid conceptualisation of 'lieux de mémoire' and from his influential distinction between 'milieux de mémoire' and 'lieux de mémoire'. According to Nora, '[t]here are lieux de mémoire, sites of memory, because there are no longer milieux de mémoire, real environments of memory'. 2 My examination of Pamuk's The Black Book and Snow is implicitly a journey from a 'lieu de mémoire' that can be an Ataturk statue to a 'milieu de mémoire' that can be an abandoned Armenian house in Kars or the novelistic space in which such an architectural site is monumentalised, that is, given a monumental significance in the text. Moreover, Nora's definition of 'lieux de mémoire' can itself be useful here in the sense that it is an expansive category of varied memory-sites that can refer 'to the archives as well as to the tricolor; to the libraries, dictionaries, and museums as well as to commemorations, celebrations, the Pantheon, and the Arc de Triomphe; to the Dictionnaire Larousse as well as to the Wall of the Fédérés [... $]^{3} .{ }^{3}$ On this basis, I examine monuments and the process of monumentalisation as they are embodied and effaced, in an Ataturk statue and in Armenian architectural remains, in the object and the novelistic space in which it is reimagined, as an act of politics and an intervention in the political. Accordingly, I aim to show how specific instances in Pamuk's novels negotiate the construction of monumentalisation and the dynamic and sometimes subversive unravelling of monumental space in its different guises: imbricated in a network of historical particulars, lived and vandalised physically and imaginatively, and textually rendered visibly invisible.

In his seminal work The Production of Space, Henri Lefebvre discusses monuments in a densely suggestive passage:
A spatial work (monument or architectural project) attains a complexity fundamentally different from the complexity of a text, whether prose or poetry. As I pointed out earlier, what we are concerned with here is not texts but texture. We already know that a texture is made up of a usually rather large space covered by networks or webs; monuments constitute the strong points, nexuses or anchors of such webs. The actions of social practice are expressible but not explicable through discourse; they are, precisely, acted - and not read. A monumental work, like a musical one, does not have a 'signified' (or 'signifieds'); rather, it has a horizon of meaning: a specific or indefinite multiplicity of meanings, a shifting hierarchy in which now one, now another meaning comes momentarily to the fore, by means of — and for the sake of - a particular action. [...] To the degree that there are traces of violence and death, negativity and aggressiveness in social practice, the monumental work erases them and replaces them with a tranquil power and certitude which can encompass violence and terror. ${ }^{4}$

Starting from Lefebvre's complex understanding of monuments and moving from the space of social practice to the novelistic space in which it is reconfigured, I address, in Pamuk's two novels, the textures of specific passages in which monuments form the anchors of the narrative web. I emphasise how these passages

\footnotetext{
${ }^{2}$ Pierre Nora, 'Between Memory and History: Les Lieux de Memoire', trans. Marc Roudebush, Representations, 26 (1989), p. 7.

${ }^{3}$ Nora, 'Between Memory and History', p. 12.

${ }^{4}$ Henri Lefebvre, The Production of Space, trans. Donald Nicholson-Smith (Oxford: Blackwell, 1991), p. 222.
} 
mediate a dynamic process of monumentalisation that works in the texts and their contexts thus revealing, beneath the 'tranquil power and certitude' of Ataturk monuments and of spaces that have unofficial memorial value in Turkey, horizons of meaning that comprise 'violence and terror'. In seeking these 'horizons of meaning' across spatial, historical, and textual axes in the two novels and their contexts, I consider the multiplicity, specificity, and shifting hierarchy of meanings emerging as a result both of various forms of narrated actions in the represented monumental space and of the actions of the texts that shift between realist and experimental techniques in their representation of different spaces and acts of monumentalisation.

Thus, I look at how certain passages in Pamuk's two novels invite a revisiting of psychological processes, marginal performances, ambivalent forms of resistance, and overdetermined layers of discursive violence and violent histories that mark the texture of monumental space and the act of monumentalisation. As such, this essay is, at an implicit level, a reflection on the ways in which Pamuk's The Black Book and Snow supplement and qualify theoretical approaches to monuments and monumentalisation-as expressed not only in Nora's and Lefebvre's works but also elsewhere in spatial theory and cultural historical and cultural geographical studies. Particularly, this is part of the larger project of rethinking the political significance of monumentalisation in Turkey beyond the commonplace banality of politics and through Pamuk's oeuvre. ${ }^{5}$

The following discussion consists of close readings of Pamuk's surrealistic, elliptical, marginal, and carnivalesque renderings of action in monumental space as well as of the moments in which he gives textual prominence to non-monumental spaces thus discursively monumentalising these spaces. These readings aim at unearthing the complex nexus of terror and taboo that underlies the process of monumentalisation as it mutates from the actual spaces of Turkey and its political history to the imaginative spaces of Pamuk's novels. The methodology and rationale of this short study therefore represent a multidisciplinary critical intervention that establishes the possibilities of dynamic readings of The Black Book and Snow and of Turkish history and politics, eclectically, at the intersections of literary studies, historical and cultural geography, social and spatial theory, historiography, and political psychology, and fluidly, across the spaces of the ontological, epistemological, textual, and theoretical. At the heart of this complex approach is monumentalisation as object, theory, historical-political-social practice, literary motif, and shifting metaphor.

Before engaging with the close readings, I present brief reflections on the relationships of terror and taboo to monumental space. W. J. T. Mitchell explains three main forms of violence in relation to public art:

(1) the image as an act or object of violence, itself doing violence to beholders, or 'suffering' violence as the target of vandalism, disfigurement, or demolition; (2) the image

\footnotetext{
${ }^{5}$ See my forthcoming monograph Monumental Space in the Post-Imperial Novel: An Interdisciplinary Study (London and New York: Continuum, 2011).

Although I use aspects of this theoretical and methodological framework in this article, I neither explain it systematically nor delve into its complexities for two reasons. First, length constraints on the present short study make it impossible to engage with the details of such a large project without being extremely selective. Secondly, the purpose of this article and that of the monograph are distinct: this article is specifically an exploration of the political and historical implications of 'monumentalisation' and its relations to terror and taboo in the two novels by Pamuk rather than a full-fledged development of the multidisciplinary theoretical framework which is referred to here and extensively explained in the monograph.
} 
as a weapon of violence, a device for attack, coercion, incitement, or more subtle 'dislocations' of public spaces; (3) the image as a representation of violence, whether a realistic imitation of a violent act, or a monument, trophy, memorial, or other trace of past violence. ${ }^{6}$

I am using Mitchell's schema not only to narrow down its conceptualisation of violence in relation to public art by underlining the ideological, material, and psychological forms of violence and terror that operate in, through, and against monumental space — and hence to take Lefebvre's earlier point further-but also, and more importantly, to set this schema as a starting point for analysing Pamuk's novelistic engagement with the violence of monumentalisation in its multifarious manifestations in twentieth-century Turkey: as an official act of the state in relation to its historical records and the collective memory of its people and as a physical or discursive space in which terror occurs, is remembered, or is effaced.

Violence and terror are more often than not symptoms of oppression or repression that involve forms of prohibition such as taboos. In this context, it is useful to consider Gertrud Koch's Freudian division of taboos into two categories:

[T]aboos which relate to something viewed as holy, and are implemented in order to increase the sense of awe and respect for the sacred object; and taboos which have an exclusive function, segregating and banishing what is considered dirty or dangerous. In any case, breaking the taboo would result in a contamination of the sacrosanct tabooed object or person, while in the second case violation of the taboo sullies the taboobreaker.

Monumentalisation involves expressions of taboo or an aggressive reaction against a taboo since monument construction is an affirmation of the 'sacred' status of the monumentalised figure and, frequently, an erasure of all 'dirty or dangerous' traces in its space while monument destruction entails a 'violation' of a taboo. As I will show, Pamuk's The Black Book and Snow complicate the relation of monumentalisation to taboo by presenting novelistic textures that mimic and subvert these two forms of taboo either by relegating the tabooed (in the sense of awfully respected) Ataturk statues and the references to attacks against these statues to a marginal position in the text or by repeating references to the tabooed (in the sense of proscribed) Kurdish and Armenian issues.

In The Black Book and Snow, Pamuk addresses two key moments in the Turkish political drama in the last two decades of the twentieth century. The fictional timeframe of The Black Book is 9 months before the military coup that swept over Turkey in $1980 .^{8}$ In Snow, the main event is a play that turns out to be the start of a repressive military coup against the Kurds and the Islamists in the 1990s. This period was marked by violent confrontations between the Turkish army and the PKK (or the Kurdistan's Workers' Party) and by what has been described as 'the post-modern coup' orchestrated by 'an alliance of secularists led by the Turkish military' in June 1997 to bring down a coalition headed by the Islamist Refah

\footnotetext{
${ }^{6}$ W. J. T. Mitchell, 'The Violence of Public Art: Do the Right Thing', in W. J. T. Mitchell (ed.), Art and the Public Sphere (Chicago, IL: University of Chicago Press, 1992), pp. 37-38. I am not equating 'violence' and 'terror' but rather considering the numerous physical and psychological operations of violence which comprises terror in a strict sense.

${ }^{7}$ Gertrud Koch, 'Between Fear of Contact and Self-Preservation: Taboo and its Relation to the Dead', trans. Rachel Leah Magshamrain, New German Critique, 90 (2003), p. 74.

${ }^{8}$ The coup, which started on 12 September 1980, succeeded two preceding coups in 1960 and 1971.
} 
party. ${ }^{9}$ From this perspective, I aim at showing that Pamuk's representation of monumental space in a number of apparently marginal and scattered passages in The Black Book and Snow functions as the groundwork for addressing, first, the powerful nexus of terror and taboo in the two key moments-1980 and 1990sand also in the multilayered history and the troubled memory of the Turkish Republic and, secondly, Pamuk's ingenious treatment of monumentalisation as a mode of political critique and of ethical engagement with history.

In order to understand the issues that are at stake here, we must look briefly at the history of Mustafa Kemal Ataturk's role in marking twentieth-century Turkish politics and the Turkish monumental space. After the defeat of the Ottomans at the hands of the Allies in the First World War and the signing of the Mudros armistice on 30 October 1918, Mustafa Kemal (who later took the name of Ataturk), as Brigadier in the Turkish army, strove to reunite the people and to reorganise the army. Through military action and diplomatic manoeuvring, he succeeded in overturning a Greek invasion of Turkey and in forcing the Allies to withdraw. ${ }^{10}$ Ataturk's accomplishments provided the basis for the establishment of the Turkish Republic which the Turkish parliament, the Grand National Assembly, declared in Ankara on 29 October 1923. At the head of the Turkish Republic, Ataturk introduced a number of reforms including the secularisation of the state, the Latinisation of the Turkish alphabet, the adoption of the Christian calendar and of Western dress, and the improvement of women's role in Turkish society. Notwithstanding his revolutionary achievements, Ataturk has been recently criticised especially in three respects which Andrew Mango, in his biography of the Turkish leader, sums up as follows: 'that he did not establish democratic government, that his policy of secularism divided Turkish society and severed the links between the rulers and the ruled, and that he suppressed ethnic diversity and, in particular, denied the rights of the large indigenous Kurdish population'. ${ }^{11}$ As the subsequent discussion will show, both the cultural revolution and the historical failings of the Kemalist project are significantly relevant to an analysis of the monument making enterprise in Turkey and to an understanding of monumentalisation as an idea with strong political resonances in Pamuk's oeuvre.

Ataturk's introduction of figural representation to Turkish monument making epitomised the cultural revolution and the secularisation measures which he imposed in as much as his commissioning the great number of statues that represent him personally and that emphasise his image 'as a supernatural human, more specifically, as a progenitor of the whole nation and the country' reflected his role in promoting his public image as a cult figure. ${ }^{12}$ In this respect, Mango notes that the Turkish leader 'established his own cult by encouraging the erection of his statues'. ${ }^{13}$

\footnotetext{
${ }^{9}$ Asli Aydintasbas, 'The Malaise of Turkish Democracy', Middle East Report, 209 (1998), p. 32. Refah won 18.8 per cent of the popular vote in the 1994 municipal elections and 21.4 in the 1995 general elections. See Ben Lombardi, 'Turkey-The Return of the Reluctant Generals?' Political Science Quarterly, 112(2) (1997), pp. 191-215, which discusses the rise of political Islam in Turkey and its conflict with the Kemalist ideology.

10 Andrew Mango, Ataturk (London: John Murray, 1999), pp. 182-357.

11 Mango, Ataturk, p. 536.

${ }^{12}$ Esra Ozyurek, 'Miniaturizing Atatürk: Privatization of State Imagery and Ideology in Turkey', American Ethnologist, 31(3) (2004), p. 382. For a discussion of Ataturk's promotion of figural representation against the Islamic tradition that prohibited such practice, see Klaus Kreiser, 'Public Monuments in Turkey and Egypt, 1840-1916', Muqarnas, 14 (1997), pp. 103-117; Metin And, 'Ataturk and the Arts, with Special Reference to Music and Theater', in Jacob M. Landau (ed.), Ataturk and the Modernization of Turkey (Boulder, CO: Westview; Leiden, The Netherlands: Brill, 1984), p. 228; and Mango, Ataturk, pp. 411, 458.

${ }^{13}$ Mango, Ataturk, p. 463.
} 
After the assassination plot which targeted him in 1927, Ataturk showed his 'determination to stamp his personality on the new Turkish state' by means of monuments. ${ }^{14}$ Ozyurek's and Mango's comments are useful here because they indicate an idea and ideology of monumentalisation that largely defined the relationship of Ataturk to the Turkish state and that accompanied the repression of dissident political expression.

The imbrication of the monument making industry in Turkey with political affairs and the mirroring relationship ${ }^{15}$ between the Ataturk cult and Ataturk statues are also at the basis of the 1951 law that criminalised any insulting expression vis-àvis Ataturk's memory in as much as they underlie the various forms of resistance to this law by groups in conflict with Kemalist ideology, namely Islamists and the PKK. The 1951 law and the great proliferation of Ataturk monuments in Turkey articulate the complex taboos that overdetermined the relationship of Ataturk and his statues to major conflictual aspects of contemporary Turkish politics. Moreover, the Ataturk cult, which was the result of Mustafa Kemal entering the political stage at a moment of ultimate crisis in Turkey, resurfaced forcefully whenever the Turkish people and, more importantly, the ultra-Kemalist Turkish army felt that the principles of the Turkish Republic were endangered by Islamists, Kurds, or other groups perceived as being at odds with Kemalism. ${ }^{16}$

On the basis of the foregoing brief overview of the Ataturk cult and its relations to the politics of monumentalisation in twentieth-century Turkey, I find that 'the sense of awe and respect', which Gertrud Koch, in the aforementioned quote, employs as a characteristic of taboo of the first kind, is an appropriate description of the tabooed dimension of Ataturk statues. With respect to Turkish history and politics, the second kind of taboo can refer to a number of 'dangerous' topics that have been approached uneasily on national and international levels since they threatened both the Ataturk cult and Kemalist ideology: the possibilities of diverse evaluations of the Kemalist legacy from the perspective of revisionist historiography, the Kurdish question, and the Armenian massacres. These topics are tabooed precisely because they involve forms of terror perpetrated in the visage of the Turkish Republic. In The Black Book and Snow, Pamuk boldly and insightfully unearths traces of terror and taboo by means of an imaginative engagement with the act of monumentalisation and its politics.

In one of the most brilliant passages of The Black Book, Pamuk weaves history, myth, and apocalypse in a surreal vision of Ataturk statues coming alive. The passage narrates a conversation between one of the alter egos of the main character Galip and a young man in the central square of an unnamed Anatolian town. Their discussion focuses on a newspaper column presumably written by Galip's journalist cousin Celal:

First we discussed the statue of Atatürk, who was pointing at the bus depot, as if to indicate that there was only one thing worth doing in this wretched town and that was to leave it. Then I happened to mention a column you'd written, in which you'd mentioned

\footnotetext{
${ }_{15}^{14}$ Mango, Ataturk, p. 458.

${ }^{15}$ In this article, I use the 'mirroring' metaphor to refer to a notion of bipolarity whereby one pole both reflects and reinforces the other.

${ }^{16}$ See Jerrold M. Post, 'Narcissism and the Charismatic Leader-Follower Relationship', Political Psychology, 7(4) (1986), pp. 675-688; and Vamik D. Volcan and Norman Itzkowitz, The Immortal Ataturk: A Psychobiography (Chicago, IL: University of Chicago Press, 1986). For an analysis of transformations in the production and consumption of Ataturk imagery especially in the wake of the Islamist surge in the 1990s, see Ozyurek, 'Miniaturizing Atatürk', pp. 374-391.
} 
that there were more than ten thousand statues of Atatürk in the country as a whole. You'd gone to say that on the day of the apocalypse, when thunder and lightning ripped across the dark sky and the earth rolled beneath our feet, all ten thousand of those fearsome statues would come back to life. Whatever their poses, whatever their attire-be they dressed in European clothes speckled with pigeon droppings or in the fully decorated uniform of a field marshal, wearing top hats and ghostly capes, or atop rearing stallions with large male organs - they would, you said, begin to turn on their pedestals, and how beautifully you described these pedestals and the countless flowers, wreaths, flies, dusty buses, and horse carts that had encircled them over the years, and the soldiers wearing uniforms that stank of sweat, and the schoolgirls, whose uniforms stank of mothballs, gazing up at these stone Atatürks, year in and year out, as they sang the national anthembut come the apocalypse they would begin to move; one by one they would step off their pedestals, crushing the flowers and wreaths beneath their feet to vanish into the night. This passionate youth had, it now emerged, read the selfsame column, and how it had fired him up to read of our wretched citizens, quaking behind their shuttered windows, cowering to the roar of the apocalypse as the earth swayed and the sky split in two, and hearing the rumble of bronze boots and marble hooves in the street outside. ${ }^{17}$

This excerpt from The Black Book is strongly reminiscent of a passage in Milan Kundera's The Book of Laughter and Forgetting in which the latter describes 'ghosts of monuments', that have been destroyed by the consecutive regimes, '[w]andering the streets that do not know their names' and 'springing up in Bohemia by the thousands, springing up like weeds among ruins, like melancholy flowers of forgetting'. ${ }^{18}$ We can compare Kundera's almost explicit political critique by means of the surreal image to Pamuk's implicit historical and political commentary by means of the apocalyptic image of Ataturk statues coming alive and haunting the streets of Turkey. Kundera embeds his image of 'ghosts of monuments' in an informative passage that comments on the historical details underlying successive changes in the naming of a particular street in Prague. Kundera presents this chameleonic process of street-naming as a means of forming and deforming the Czech people's collective memory thus 'brainwashing it [the street and the people] into a half-wit' ${ }^{19}$ In contrast, Pamuk's image of Ataturk statues coming alive represses the historical subtext of its apocalyptic drama as it elliptically alludes to polemical details in the histories of the Kemalist and postKemalist periods and combines a sense of satiric comedy and bitter irony with a heightened degree of terror.

A surreal image of Ataturk and of statues coming alive, in this case emerging in what resembles a wax museum imagined in the protagonist's dream, appears in Adalet Agaoglu's novel Olmeye Yatmak (Lying Down to Die). This dream has been approached by several critics including Jale Parla and Sibel Irzik who notes that 'Atatük as the father of the nation seems to be quite a permanent feature of many a character's dreams or nightmares in the Turkish novel'. ${ }^{20}$ Although Pamuk does not present the image of Ataturk statues coming alive as part of a dream, he endows the surreal performance with a nightmarish ambience that is psychologically and historically significant.

17 Orhan Pamuk, The Black Book, trans. Maureen Freely (London: Faber, 2006), p. 357.

${ }_{18}$ Milan Kundera, The Book of Laughter and Forgetting, trans. Aaron Asher (London: Faber, 1996), p. 217.

19 Kundera, The Book of Laughter and Forgetting, p. 217.

${ }^{20}$ Adalet Agaoglu, Olmeye Yatmak [Lying Down to Die] (Istanbul: Yapi Kredi Yayinlari, 1998). Jale Parla, Don Kisot'an Bugune Roman [The Novel from Don Quixote to Today] (Istanbul: Iletisim Yayinlari, 2000). Sibel Irzik, 'Allegorical Lives: The Public and the Private in the Modern Turkish Novel', South Atlantic Quarterly, 102(2-3) (Spring/Summer 2003), p. 553. 
The garbs that the Ataturk statues don for their performance in surreal space function as metonyms and metaphors of significant elements in Kemalist policy: the European clothes and top hats hint at Turkey's ambivalent relations with the Europeans throughout the twentieth century and at the controversial Westernising measures including those that enforced the replacement of the fez with the hat while the field marshal's uniform reminds us of Ataturk's dual role as political leader and army commander and of the continued involvement of the army in Turkish political affairs. ${ }^{21}$ These metaphorical and metonymic relations are imbued with an irony that functions on several levels. Primarily, the awakening of thousands of Ataturk statues satirises the monument making fever that Mustafa Kemal encouraged and that, in the last decades of the twentieth century, involved both the commodification of the leader's image and its use as a political weapon. ${ }^{22}$ Moreover, Pamuk pictures Ataturk's multiple garbs as smeared with pigeon droppings. The image seems to undermine the sacred space of the monument and the superhuman qualities which the monument articulates and to highlight instead its earthy ordinariness thus indirectly deflating the triumphalist rhetoric that usually underwrites monumental space. A similar image occurs in Pamuk's The New Life where the narrator 'chide[s] the town pigeons for dropping on the Atatürk statue'. ${ }^{23}$ In an interview with Arminta Wallace, Pamuk comments ironically on the controversy that surrounded this subject:

One row which has been going for several months now is that, in The New Life, I supposedly made jokes about Kemal Ataturk, the founder of the Turkish Republic. I said pigeons were shitting on Ataturk's statue, and also that a poster of Ataturk was smiling ironically at people who were drinking themselves to death in a bar, and they fished that out to attack me, very aggressively. In Turkey right now, the Islamic fundamentalists are attacking Ataturk so a controversy arose in the popular newspapers as to whether I might be in the pay of the fundamentalists.

Of course I'm not, and of course I don't hate Ataturk, but I'm not one of those people — and we have them in Turkey, believe me-who say "I like trees because Ataturk used to like trees too". Now this isn't censorship either, but the next time you write about Ataturk you get self-conscious and say, OK, maybe pigeons should not shit—or next time, maybe I'll write "Dear leader, pigeons in this lovely country never shit on Ataturk's statue". 24

While taboo and imaginative resistance to it envelop the image of pigeon droppings on the Ataturk statue, the description of the 'rearing stallions with large male organs' satirises the masculinist iconography which is oftentimes a main feature of triumphalist monuments. ${ }^{25}$ Nevertheless, the subtly comic touch in the

\footnotetext{
${ }^{21}$ Mustafa Kemal is said to have declared that the earlier Ottoman headdress, the fez, 'sat on the heads of our nation as an emblem of ignorance, negligence, and fanaticism and hatred of progress and civilization'. Quoted in Resat Kasaba, 'Kemalist Certainties and Modern Ambiguities', in Sibel Bozdogan and Resat Kasaba (eds), Rethinking Modernity and National Identity in Turkey (Washington, DC: University of Washington Press, 1997), p. 25. Reflecting on the upstart behaviour of some of his army comrades in the days after the establishment of constitutional rule in 1908, Mustafa Kemal stated in 1922: 'The first measure that came to my mind to combat the evil was to apply the principle that the army should withdraw from politics'. Quoted in Mango, Ataturk, p. 84. 22 Ozyurek discusses this phenomenon in 'Miniaturizing Atatürk'.

${ }^{23}$ Orhan Pamuk, The New Life, trans. Güneli Gün (New York, NY: Farrar, Strauss \& Giroux, 1997), p. 193.

24 Orhan Pamuk, Interview with Arminta Wallace, The Irish Times (1 April 1999 city ed.), p. 16.

${ }^{25}$ For commentary on gender relations in public statuary, see Janice Monk, 'Gender in the Landscape: Expressions of Power and Meaning', in Kay Anderson and Fay Gale (eds), Inventing Places: Studies in Cultural Geography (Melbourne, Australia: Longman Cheshire, 1992), pp. 123-138 and Karen Till, 'Places of Memory', in John Agnew, Katharyne Mitchell, and Gerard Toal (eds), A Companion to Political Geography (Oxford: Blackwell, 2003), pp. 289-301.
} 
passage seems to be paradoxically complicit with awe-inspiring resonances in the apocalyptic vision of the Ataturk statues coming alive.

The vision communicates the apocalyptic dimensions of Ataturk's crucial role in bringing Turkey from the era of the Ottoman sultanate-caliphate to the age of the Turkish Republic and the apocalyptic implications of the revolutionary reforms that he subsequently imposed. ${ }^{26}$ In 1925, Ataturk declared:

The sublime force of civilization pierces mountains, crosses the skies, enlightens and explores everything from the smallest particle of dust to stars... When faced with this, those nations who try to follow the superstitions of the Middle Ages are condemned to be destroyed or at least to become enslaved and debased. ${ }^{27}$

Nevertheless, it is possible to read Pamuk's apocalyptic narrative of Ataturk statues coming alive not only in relation to the birth of the Turkish Republic but also, and more significantly, in relation to major turning points in its recent history. My argument here is that the awe-inspiring aspects of the apocalyptic narrative become more politically and historically meaningful if we consider the highly important fact that the time-frame of The Black Book is 9 months before the 1980 military coup.

The 1980 coup came at the peak of a period of political agitation, violence, and economic and social uncertainties in Turkey. While proclaiming that their ultimate aim was to reinstate democracy, the leaders of the 1980 military coup took several drastic measures including: the dissolution of the National Assembly; the ousting of Suleyman Demirel's government that had failed to stop the vicious cycle of terrorist violence between rightwing and leftwing groups; the arrest of the prime minister and his cabinet, the leader of the opposition, over a hundred deputies, several trade union officials, students, and intellectuals; the suspension of the constitution and of all political and cultural activities; and the enforcement of martial law all over Turkey. The Turkish people reacted to the coup as an inevitable event and accepted it with hardly any resistance. ${ }^{28}$ From this perspective, the image of "wretched citizens, quaking behind their shuttered windows, cowering to the roar of the apocalypse [...], and hearing the rumble of bronze boots and marble hooves in the street outside ${ }^{29}$ evokes the atmosphere of resignation and awe that overwhelmed Turkey as the army carried out the coup.

Pamuk also intimates this sense of the people's awed resignation to the symbols of power in the suggestive image of 'the countless flowers, wreaths, flies, dusty buses, and horse carts that had encircled them [the statues] over the years, and the soldiers $[\ldots]$, and the schoolgirls, [...] gazing up at these stone Atatürks, year in and year out, as they sang the national anthem'. ${ }^{30}$ The image conveys a monotonous

\footnotetext{
${ }^{26}$ Though this will not be done in this essay, it would be interesting to read Pamuk's apocalyptic narrative and some of its historical subtexts, that is the revolutionary reforms introduced by Ataturk, in the light of Walter Benjamin's comments in 'Theses on the Philosophy of History' where he describes apocalyptic moments and apocalyptic conceptions of history: 'The awareness that they are about to make the continuum of history explode is characteristic of the revolutionary classes at the moment of their action. The great revolution introduced a new calendar. The initial day of a calendar serves as a historical time-lapse camera. And, basically, it is the same day that keeps recurring in the guise of holidays, which are days of remembrance. Thus the calendars do not measure time as clocks do; they are monuments of a historical consciousness of which not the slightest trace has been apparent in Europe in the past hundred years'. Walter Benjamin, 'Theses on the Philosophy of History', in Hannah Arendt (ed.), Illuminations, trans. Harry Zohn (London: Fontana, 1992), p. 253.

${ }_{27}$ Quoted in Kasaba, 'Kemalist Certainties and Modern Ambiguities', in Bozdogan and Kasaba (eds), Rethinking Modernity and National Identity in Turkey, p. 26.

${ }^{28}$ Jim Paul, 'The Coup', MERIP Reports, 93 (1981), p. 3.

${ }^{29}$ Pamuk, The Black Book, p. 357.

${ }^{30}$ Pamuk, The Black Book, p. 357.
} 
dynamism that almost amounts to stasis. Pamuk's description of horse carts encircling Ataturk statues for years and of soldiers and schoolgirls dressed in squalid costumes and engaged in a continuous commemorative exercise subtly parodies the rituals of cultic devotion by revealing the tawdriness of a crowd repeating nationalist gestures almost passively if not indifferently. As such, the contrasting images of a Turkish society immersed in commemorative monotony and of Ataturk statues awakening apocalyptically implicitly communicate the contrasting facets of Kemalism in twentieth-century Turkey. On the one hand, the apocalyptic image indicates the possibility of a transformative revolution as a revival of the birth of the Turkish Republic. On the other hand, the image of commemorative monotony undermines the revolutionary implications and instead reveals social paralysis. After Ataturk's death, both the successive governments and the military coups that punctuated twentieth-century Turkish politics largely failed to realise a true transformation on social and political levels. In this respect, while the leaders of the 1980 coup declared that their intention is ultimately to re-establish democracy, their policies and actions did not always reflect democratic practice. ${ }^{31}$ Exploring the idea of the 'counter-monument', James E. Young writes:

Like other forms of art, the monument is most benign when static: there when you face it, gone when you turn your back. But when it begins to come to life, to grow, to shrink, or change form, the monument [here, Young's notion of the counter-monument] may become threatening. No longer at the mercy of the viewer's will, it seems to have a will of its own, to beckon us at inopportune moments. ${ }^{32}$

Such an envisioning of the awesome dimension of the monument coming to life and acting as an independent will seems almost impossible to elaborate in the analytical approaches of cultural geographers or art historians. This vision requires both a certain amount of suspension of disbelief and an attempt at securing belief through the notions of miracle and apocalypse which the literary narrative can afford. Clearly, the image of an apocalyptic awakening of Ataturk statues is imaginary. However, the fictionality of the image does not prevent its relevance to social and political reality. Pamuk's narrative of Ataturk statues coming alive imaginatively expresses the complex and sometimes contradictory aspects of Turkish cultural, social, and political dynamics as these negotiate the trajectories of the revolutionary ideal, the cult of the leader, authoritarianism, and democratic change. By means of the apocalyptic trope that both literary discourse and political discourse employ, Pamuk's narrative effects a blasting of one-sided historical accounts thus substituting multiplicity for a linear and univocal reading of Ataturk's legacy and its refractions in twentieth-century Turkey. While the apocalyptic trope often functions in the discourses of politicians as a technique of rhetorical violence and ideological manipulation couched in quasi-religious terms, here it performs the complex and paradoxical role of emphasising and parodying the violence of a history where stasis and repetition masquerade deceptively as dynamic moments: incomplete revolutions, repressive coups, commemorative monotony, and social paralysis.

Thus Pamuk's representation of an apocalyptic awakening of Ataturk statues and my reading of it contribute together to activating several dimensions in the

\footnotetext{
${ }^{31}$ See Lombardi, ‘Turkey', pp. 205, 206, 208-209 and Jim Paul, 'The Coup', p. 3.

32 James E. Young, 'The Counter-Monument: Memory against Itself in Germany Today', in Mitchell (ed.), Art, p. 66.
} 
monument's 'horizon of meaning' which Lefebvre identifies as 'a specific or indefinite multiplicity of meanings, a shifting hierarchy in which now one, now another meaning comes momentarily to the fore'. ${ }^{3}$ Among these various meanings are terror and taboo and their relations to monumentalisation in Pamuk's text and its contexts. On the one hand, the image of Ataturk statues coming alive and spreading awe through 'the rumble of bronze boots and marble hooves, 34 undermines what Lefebvre describes as the monument's apparent 'tranquil power and certitude which can encompass violence and terror'. 35 On the other hand, by textually demonstrating the making of taboo-by means of the surreal image and the figurative representation of the apocalyptic moment-and by imaginatively intervening in the tabooed Turkish monumental space and tabooed Turkish history, this passage from Pamuk's The Black Book is a political gesture which both mimics and subverts taboo and thus participates in the negotiation of monumentalisation and monumental space in the context of the history of the Turkish Republic.

The complex reasons behind the three military coups in Turkey's recent history (1960, 1971, and 1980) included 'ineffective political leadership, the growing challenge of Islam, economic malaise, and PKK terrorism'. ${ }^{36}$ In 1997, the military carried out what has been referred to as a 'post-modern coup' against the Islamist Refah party which was at the head of a coalition that had governed the country for 12 months before it was brought down. The 1990s were also a period of heightened PKK activities and serious economic problems. Pamuk orchestrates the political and socioeconomic drama of the 1990s in his most overtly political novel, Snow. In this novel, I focus first on an incident featuring a performance that involves an Ataturk statue. The main character here is Sunay Zaim who stages the theatrical event that turns out to be the start of a military coup against Islamists and Kurds in the northeastern Anatolian town of Kars. The incident occurs in the context of Sunay's campaign to play the role of Ataturk in a film:

He [a high-ranking officer] didn't soften one bit when he saw Sunay quaking with remorse and fear; rather, he ridiculed Sunay for propounding his own political views in the guise of the 'man chosen to be Atatürk' and alluded to Sunay's short visit two days earlier to the town of his birth, during which he had played the 'people's politician'. (Cheered on by convoys of cars and crowds of tobacco manufacturers and unemployed men, Sunay had climbed up to the statue of Atatürk in the town's main square and inspired even more applause by squeezing Atatürk's hand; when a reporter from a popular magazine then asked him whether he thought he might leave the stage one day to enter politics, Sunay answered, 'If the people want me'.) The prime minister's office announced that the Atatürk film was to be postponed indefinitely. ${ }^{37}$

Primarily, we must pause at the textual marginalisation of the performance with the Ataturk statue. The parenthetical gesture is a textual embodiment of taboo while the marginalised incident paradoxically negotiates various political, socioeconomic, and cultural issues that are central in the context of both contemporary Turkish politics and its refractions in Snow.

\footnotetext{
${ }^{33}$ Lefebvre, The Production of Space, p. 222.

34 Pamuk, The Black Book, p. 357.

${ }^{35}$ Lefebvre, The Production of Space, p. 222.

${ }^{36}$ Lombardi, 'Turkey', p. 213.

${ }^{37}$ Pamuk, Snow, trans. Maureen Freely (New York, NY: Vintage, 2005), p. 193.
} 
In order to approach Sunay's performance with the Ataturk statue during his campaign to play Ataturk in a film, we should shed some light on a key historical fact. Actors were not allowed to play the role of Ataturk in plays and films until the 1980s. Instead, Ataturk declared that he desired to "portray himself, that he wear his old clothes and act out what he had done in previous years'. ${ }^{38}$ In light of this fact and of the role of Ataturk monuments as tabooed embodiments of the Ataturk cult, Sunay Zaim's attempt to play the role of Ataturk and his casual behaviour with the Ataturk statue may have subversive implications. In this respect, Bakhtinian and post-Bakhtinian interpretations of the carnivalesque provide us with an appropriate framework to address the subversive potential of Sunay's performance of politics and the politics of his performance. In Rabelais and His World, Bakhtin describes popular carnival culture as one that is opposed to the official feast since it 'marked the suspension of all hierarchical rank, privileges, norms, and prohibitions'. ${ }^{39}$ Bakhtin's statement can be useful here if we move away from the specific carnival forms of the Middle Ages and Renaissance which he describes in order to approach the carnivalesque as a socio-political phenomenon in twentieth-century popular culture. Specifically, the carnivalesque must be viewed here in the particular historical context of 1990s Turkey as reflected in the passage from Snow.

Before the 1990s, a Turkish actor proclaiming that he would play the role of Ataturk was an act of defiance since it iconoclastically overturned established hierarchical distinctions and it neglected official prohibitions by breaking an almost sacred taboo. In this respect, the carnivalesque dimension is especially expressed in Sunay's gesture of shaking the hand of the Ataturk statue since, from one perspective, this gesture not only undermines the surhumanity of the statuesque and claims a degree of equality with the represented figure but also involves an informal if not irreverent attitude to the tabooed leader's figure. ${ }^{40}$ Yet, from a different perspective, it is also possible to interpret Sunay's gesture as conservative because it reproduces instances in which people reverently shook Ataturk's hand and it may even reflect an affectionate stance towards the leader's memory.

In all cases, monumental space provides here a stage for various reversals and mirroring effects: leader and follower, life (Sunay) and death (the statue), politics and art. The political element is salient in all of Sunay's cultural gestures of identification with Ataturk's figure: staging a Kemalist play, playing Ataturk in a film, squeezing the hand of Ataturk in the monumental square and-more dangerously-playing the role of the leader in the military coup against the Islamists and Kurds that are presumably threatening Kemalist ideology. On this basis, it is essential to carefully examine the complex implications of the doubling and mirroring effects between politics and performance in this passage.

Sunay describes his theatrical practice as 'Brechtian and Bakhtinian'. 41 Therefore, the intersection of politics and performance here allows two perspectives: one Brechtian and the other Bakhtinian. The key element in formulating the

${ }^{38}$ Ozyurek, 'Miniaturizing Atatürk', p. 384.

39 Mikhail Bakhtin, Rabelais and his World, trans. Helene Iswolsky (Bloomington, IN: Indiana University Press, 1984), p. 10.

40 Ironically, Sunay's last name 'Zaim' signifies 'leader'. This sheds an ironic light on Sunay's possible attempt at identification with Ataturk's figure.

${ }^{41}$ Pamuk, Snow, p. 138. 
Brechtian perspective is to consider the meanings of Sunay's performance as the 'people's politician'. In an ingenious investigation of post-Soviet politics, titled Virtual Politics: Faking Democracy in the Post-Soviet World, Andrew Wilson contends that, with similar but not identical examples in the West and in the former USSR, "the post-Soviet world has its own unique breed of "political technologists", who bestride an entire culture of politics-as-performance, with common patterns and repeat performances'. ${ }^{42}$ Through the example of Sunay, Pamuk presents, in a Turkish context, the drama of populism and the ritualised show of democracy as they get enacted in spaces that almost perversely reflect each other: the theatrical stage and the political stage. In a conversation titled 'On the Theatricality of Fascism', Brecht looks at 'how the oppressors of our times make theatre - not in their theatres, but on the streets and in the assembly halls, as well as in their private homes, diplomatic offices and conference rooms'. ${ }^{43}$ Although Brecht's comment relates particularly to Hitler's Germany, it can also be useful in explaining the interpenetration of politics and performance in Snow, particularly in the selected passage. On the stage of the National Theatre in Kars where he carries out the coup and on the stage of the Ataturk statue where he campaigns to play the role of Ataturk, Sunay attempts to elicit the empathy of the people by means of shock and awe. Here the 'people' may refer both to the audience of the political performance and to the audience of the theatrical performance.

Therefore, Sunay's reply 'if the people want me' signifies: If the people are moved by my performance and are convinced that my will emerges from their own. This represents an act of faking democracy in the context of political theatrics. It is hence an implicit and subtle novelistic comment on the rhetoric of democracy as enunciated by military coup leaders and successive governments in Turkey. Nowadays, the issue of democracy is highly significant in Turkey as the Republic negotiates its thorny path into the European Union. In her introduction to a politically dense conversation with Orhan Pamuk, Maureen Freely writes that a crucial question for people in Turkey concerned the distinction between two forms of democracy: what they saw as 'a struggle between what some call "tutelary democracy" (in which the army holds the reins, stepping in whenever it sees "the nation" straying from the righteous path) and something more in line with the social democracies of Europe'. ${ }^{44}$ Accordingly, the drama of politics as performance and performance as politics in this passage unravels the chameleonic figure of democracy in the recent history of the Turkish Republic.

Returning to the Bakhtinian perspective, the intricate relationship of performance and politics might justify a reading of the carnivalesque performance in this instance as a 'safety valve mechanism'. Critiquing the politics of carnivalesque forms, Terry Eagleton argues that carnival is 'a licensed affair in every sense, a permissible rupture of hegemony, a contained popular blow-off as disturbing and relatively ineffectual as a revolutionary work of art'. ${ }^{45}$ Clearly, Sunay's various appropriations of the Ataturk figure, on the political stage or the theatrical stage, can be regarded as a revolutionary work at the intersection of life

\footnotetext{
42 Andrew Wilson, Virtual Politics: Faking Democracy in the Post-Soviet World (New Haven, CT: Yale University Press, 2005), p. 48.

${ }^{43}$ Bertolt Brecht, 'On the Theatricality of Fascism', in Bertolt Brecht, Brecht on Art and Politics, edited by Tom Kuhn and Steve Giles, part five edited by Stephen Parker, Matthew Philpotts and Peter Davies, trans. Laura Bradley, Steve Giles, and Tom Kuhn (London: Methuen, 2003), p. 195.

44 Maureen Freely, 'A Conversation with Orhan Pamuk', Granta, 93 (2006), p. 108.

45 Terry Eagleton, Walter Benjamin: Towards a Revolutionary Criticism (London: Verso, 1981), p. 148.
} 
and art. $^{46}$ Yet, this blurring of boundaries between political action and the artistic/theatrical act is not an absolutely 'ineffectual' and 'licensed affair' because it may be a tactical means to subversive ends as it seeks to evade official protocol and discipline through its artful devices. Still, the textual marginalisation of Sunay's performance may be mimicking the spatial marginalisation of carnival culture and the restriction of its effects in a contained unofficial sphere. In this respect, Bakhtin emphasises carnival culture 'extraterritoriality in a world of official order and official ideology' ${ }^{47}$ Instead, in Pamuk's text, the spatiality of the carnivalesque is significantly different from that of carnival as described by Bakhtin. Here, the carnivalesque intervenes in the territory of power and in a markedly official space, the monumental space which represents the leader's celebrated image. Moreover, Sunay's performance indirectly incites the reaction of power through the high-ranking official's attitude that blends ridicule and terror and through the decision to postpone the Ataturk film indefinitely. Yet, the direct response of power on the ground and the political ramifications of the crowd's cheering (are they radically complicit in a subversive act or are they conservatively applauding an emotional outburst towards Ataturk?) are left out of the narrative. This significant present absence in the text not only creates ambivalence but also permits a multiplicity of political interpretations in relation to the Ataturk cult and Ataturk statues, their defence by Kemalists, and their popular transformations in the context of a struggle in which allegiance and resistance historically took different and often violent forms. In this way, both the allusions and ellipses in Pamuk's narrative of carnivalesque performance around the Ataturk statue implicitly perform and allow a critique of subtle forms of manipulation and repression that underlie the practice of monumentalisation.

In Snow, monumental spaces are the sites of various manifestations of violence. On this basis, we can use W. J. T. Mitchell's aforementioned schema of the three meanings of the violence of public art to approach the following motifs and issues in Snow: (1) the representations of monumental spaces commemorating violence, (2) the narration of violence against monumental spaces, and (3) the unofficial spaces that bear traces of past violence and that become monumentalised through repetition in the text. Snow communicates these meanings by narrating events and alluding to conflicts that still mark the Turkish Republic with the nexus of terror and taboo: a series of attacks against Ataturk statues, the repression of Kurds who presumably perpetrate these attacks, and the expression of the discursive/spatial struggle concerning the Armenian massacres during WWI. In an interview to the Swiss newspaper Der Tages-Anzeiger, Pamuk stated: 'Thirty thousand Kurds and a million Armenians were killed in these lands and nobody but me dares to talk about it'. This statement resulted in his being charged under Article 301/I of the Turkish Penal Code with the crime of 'public denigration' of Turkish identity. ${ }^{48}$ In Snow, Pamuk negotiates the Scylla and Charybdis of the highly sensitive Kurdish and Armenian issues by staging fictional episodes in the Anatolian town of Kars, a

\footnotetext{
${ }^{46}$ See Irzik, 'Allegorical Lives', pp. 560-564; Sibel Erol, 'Reading Orhan Pamuk's Snow as Parody: Difference as Sameness', Comparative Critical Studies, 4(3) (2007), pp. 403-432 and Mary Jo Kietzman 'Speaking to "All Humanity": Renaissance Drama in Orhan Pamuk's Snow', Texas Studies in Literature and Language 52(3) (2010), pp. 324-353 for analyses of the theatrical troupe and of the intersections between art/fiction/theatre and life history in Snow.

${ }^{47}$ Bakhtin, Rabelais, p. 154.

${ }^{48}$ Quoted in 'The Paris Review Interview', in Orhan Pamuk (ed.), Other Colours, trans. Maureen Freely (London: Faber, 2007), p. 356.
} 
place that is punctuated with monuments and sites related to the Turkish-Kurdish conflict and the Armenian massacres.

The Kurds, who now number around 25 million all over the world, were distributed, in the aftermath of the First World War and the division of the Ottoman Empire into independent nation-states, among Turkey, Syria, Iran, and Iraq. ${ }^{49}$ In Turkey, Kurds form around 20 per cent of the population and they are concentrated as a majority in southeastern Turkey near the borders with Syria, Iraq, and Iran. ${ }^{50}$ Although some Kurds supported the establishment of the Turkish Republic in 1923, they realised, after the end of the caliphate, that the Turkish state will not allow 'dual identities'. 51 There were three Kurdish rebellions in Turkey between 1925 and 1935 which were repressed by the Turkish military. In the 1970s and after almost 40 years of cessation of Kurdish militant action against the Turkish state, the radical Kurdish organisation, the PKK, was formed and expanded under the leadership of Abdullah Ocalan until his arrest by the Turkish authorities in 1999. Throughout the years, the PKK has shifted its rhetoric and politics along a continuum of Kurdish demands from separatism by means of violence to peaceful attempts at resolving conflictual issues with the Turkish government. ${ }^{52}$ In the early 1990 s, there was a particular increase in PKK attacks and in the Turkish army's actions against what it recognised as a grave terrorist threat. The human cost of the violence was thousands of Turkish and Kurdish lives. $^{53}$

Turkish repressive measures against the PKK and the Kurds have taken various forms including, in the 1930s for instance, the deportation of thousands of Kurds and the banning of the public use of the Kurdish language. ${ }^{54}$ From a socioeconomic perspective, regions with a Kurdish majority, especially southeastern Turkey, have had to cope with devastating conditions: 'By the early 1990s, less than 10 percent of adults in the Kurdish southeast had industrial jobs, and most of them tended to be in low-skilled industries'. ${ }^{55}$ Pressed by the European Union that demands Turkey's full respect of human rights and the protection of minorities as membership criteria, the Turkish government has gradually proceeded to make some improvements in Kurdish regions by legalising the use of the Kurdish language, and adopting 143 laws, a 'harmonizing law', and four reform packages which, nevertheless, have been critiqued as failing to result in important practical changes. ${ }^{56}$

The conflict between the Turkish military and the PKK is at the heart of Pamuk's Snow. In a conversation with a detective, the main character, named Ka, learns that the army and the MIT (Turkish secret services) are undertaking a campaign to punish alleged attacks on Ataturk statues and even unconscious desires for such attacks by Kurdish youths.

\footnotetext{
${ }^{49}$ Fotios Moustakis and Rudra Chaudhuri, 'Turkish-Kurdish Relations and the European Union: An Unprecedented Shift in the Kemalist Paradigm?', Mediterranean Quarterly (Fall 2005), p. 78.

50 James Brown, 'The Turkish Imbroglio: Its Kurds', Annals of the American Academy of Political Science, 541 (1995), p. 117.

${ }^{51}$ Lise Storm, 'Ethnonational Minorities in the Middle East', in Youssef M. Choueiri (ed.), A Companion to the History of the Middle East (Malden, MA: Blackwell, 2005), p. 474.

52 Brown, 'The Turkish Imbroglio', pp. 118-119.

${ }^{53}$ Storm, 'Ethnonational Minorities', p. 474.

${ }^{54}$ Storm, 'Ethnonational Minorities', p. 474.

55 Moustakis and Chaudhuri, 'Turkish-Kurdish Relations', p. 81.

${ }^{56}$ Moustakis and Chaudhuri, 'Turkish-Kurdish Relations', pp. 85-86.
} 
The more ground the army gained in its savage conflict with the Kurdish PKK guerillas, the lower became the morale of the weak, despairing, and unemployed Kurdish youths who'd fallen in with them; this situation had led some of these youths to nurture strange and frightful dreams of revenge, as was reported by quite a few of the detectives who spent their days dozing in the city's coffeehouses. They'd overheard youths discussing bomb and kidnap plots, possible attacks on the statue of Atatürk, a scheme to poison the city's water supplies, and another to blow up its bridges. ${ }^{57}$

A main target of the terrorising policy executed by Sunay Zaim's military group is Kurdish individuals accused of vandalising representations of Ataturk.

There were eyewitness reports, perhaps exaggerated, about the terror Z Demirkol and friends had been visiting on the city throughout the day: they'd raided the Mesopotamia Association, founded by a number of Kurdish nationalist youths to promote 'folklore and literature', $[\ldots]$.

Then there were the three men-two of them were barbers and the third was unemployed-who'd been implicated in an incident six months earlier in which parties unknown had poured sewer water over the statue of Atatürk that stood outside the Atatürk Work Plant; although they'd opened an investigation on these men, they'd never put them behind bars; but after beatings that had gone on all night, they'd taken responsibility for a number of anti-Atatürk incidents in the city (taking a hammer to the nose of the Atatürk statue that stood in the garden of the Trade and Industry Lycée, writing ugly remarks on the Atatürk poster hanging on the wall at the Gang of Fifteen Café, and entering into a conspiracy to use a hatchet to destroy the Atatürk statue standing outside the government offices). ${ }^{58}$

The parenthetical gesture, enclosing the enumeration of presumable anti-Ataturk events, is a textual expression of taboo with respect to the aforementioned criminal offence of insulting Ataturk's memory. Interestingly, the equally subversive act of pouring sewer water over the Ataturk statue which, according to Gertrud Koch's schema, can be described as a 'contamination of the sacrosanct tabooed object or person', ${ }^{59}$ is left out of the parentheses as though the text is tentatively mimicking the act of taboo breaking and then immediately re-establishing the boundaries of taboo through the parenthetical gesture. What is also striking in the passage is that it presents the most concentrated textual occurrence of 'Ataturk' in Snow. This is particularly ironic given that there has been serious criticism of Kemalist policy towards the Kurds. In this context, Mango writes:

The persistence of the Kurdish problem is [...] a failure of the Turkish nationalist approach, which Atatürk shared, but did not initiate. Later, however, his theories of history provided a spurious justification for a policy of assimilation. He could, of course, have tried to implement his original promise of local autonomy; but as the Kurds were (and remain) divided, and fought each other with as much gusto as they resisted attempts at control from outside; it is doubtful that autonomy would have been compatible with law and order. [...] But whatever the cause, he bequeathed the Kurdish problem to his successors. ${ }^{60}$

Mango's statement does not lay the guilt entirely on either Kemalists or Kurdish groups. Like Mango's historical analysis, Pamuk's imaginative approach to the Turkish-Kurdish conflict comprises a recognition of the debilitating divisions among Kurdish groups and an attention both to the excesses in the repressive

\footnotetext{
${ }^{57}$ Pamuk, Snow, p. 209.

${ }^{58}$ Pamuk, Snow, p. 304.

${ }^{59}$ Koch, 'Between Fear of Contact and Self-Preservation', p. 74.

${ }^{60}$ Mango, Ataturk, p. 537.
} 
reaction against the Kurds and to the latters' destitute economic condition. In the two excerpts from Snow, real or imagined attacks against Ataturk statues become the matrix for the negotiation of shared guilt and excessive violence in the Turkish-Kurdish conflict.

Examining the politics of destroying monuments, Robert Bevan contends that: 'There are contradictions, inconsistencies and a myriad of local subtleties to the meanings brought to buildings and the actions taken against them; these in themselves change over time. There is no unity of process and purpose but a cluster of interwoven vectors. And in conflicts there will always be a confusion of motives and responsibilities'. ${ }^{61}$ Pamuk reveals the interpenetration of responsibilities, the multiplicity of motives, and the complexity of agency and its 'local subtleties' in the alleged anti-Ataturk incidents and the state's reactions to them. The taboo surrounding Ataturk's memory and its monumental representations thus becomes the site of unconscious desires and/or fabricated dreams threatening Kemalist ideology. Pamuk's narrative does not reproduce clichéd interpretations of Kurdish actions as either iconoclastic resistance or mere terrorism. Rather, Snow highlights the significant roles of rumour and propaganda, radical distrust and extremist discourses of authenticity, as these fuel a cycle of violence expressed in terrorism or torture, in psychological or material forms.

Immediately after the revolutionary coup in Kars, Ka reads in the local newspaper, the Border City Gazette that: 'Disputes between Islamists, secularists, Kurds, Turks, and Azeris drive us asunder for specious reasons and reawaken old accusations about the Armenian massacre that should have been buried long ago'. ${ }^{62}$ Snow reveals the coaction of terror and taboo not only in relation to the Kurdish question but also with respect to the massacres of Armenians during WWI and in the few years between the war and the establishment of the Turkish Republic. At one point in the novel, we learn that:

\begin{abstract}
A defeatist in the crowd [of various Islamist, Kurdish, and leftist individuals meeting secretly in the Hotel Asia], slyly asked, 'And whatever happened to the millions of Armenians who once lived all across Anatolia, including Kars?' in the course of a long speech about the Crusades, the Holocaust, the American massacre of Red Indians, and the Algerian Muslims massacred by the French. But feeling pity for this man, the informersecretary did not write down his name. ${ }^{63}$
\end{abstract}

The identification of the Turkish massacre of Armenians as one item in a long list of massacres across different spatial matrices and historical epochs suggests an integrative and fluid perspective and a dynamically critical approach that transcend the memory of a closed community. In his seminal study of the intricate relations of memory, history, forgetting, and forgiveness, Paul Ricoeur writes: 'It is along the path of critical history that memory encounters the sense of justice'. ${ }^{64}$ If Ricoeur believes that history's contribution is 'in correcting, criticising, even refuting the memory of a determined community, when it folds back upon itself and encloses itself within its own sufferings to the point of rendering itself blind and deaf to the suffering of other communities', ${ }^{65}$ Pamuk's citation of various

\footnotetext{
${ }^{61}$ Robert Bevan, The Destruction of Memory: Architecture at War (London: Reaktion, 2006), p. 17.

62 Pamuk, Snow, p. 295.

${ }^{63}$ Pamuk, Snow, p. 278.

${ }^{64}$ Paul Ricoeur, Memory, History, Forgetting, trans. Kathleen Blamey and David Pellauer (Chicago, IL: University of Chicago Press, 2004), p. 500.

${ }^{65}$ Ricoeur, Memory, History, Forgetting p. 500.
} 
bloodstained historical moments in the passage above tentatively suggests the possibility of such a critical history that respects the specificity of a people's suffering while acknowledging commonality, similarity, and multiplicity.

In Snow, Pamuk evokes the history of the Armenian massacres in WWI, but he especially touches upon the massacres that happened in Kars when the Turkish Army entered the city in 1920. This narrative engagement with two successive historical moments that witnessed two different massacres does not imply that Pamuk erases the difference between the two massacres or anachronistically extends the blame for the WWI massacres to the dawn of the Turkish Republic. Rather, the evocation of the Kars events functions as a symptom of the tabooed subject of the Armenian massacres generally and of the 1920 attacks against Armenian properties and lives particularly. Inevitably, underlying Pamuk's narrative is the taboo which in Turkey still surrounds the debate on the genocidal dimensions of the WWI Armenian massacres. ${ }^{66}$ As I will show next, in Snow, the representation of monumental spaces and of spaces that become monumentalised in the text contributes to a critical history of the massacres and of the violent attacks against Armenians in Kars. This is the imaginative space where the memory of past violence encounters a potential sense of justice.

An important monumental space in relation to the history of the fall of Kars in Turkish hands is the Kazim Karabekir statue. On 28 October 1920, just when the Soviet Union recognised the province of Kars as a part of Armenia, the Turkish army, led by Kazim Karabekir, attacked Kars and then captured Kars castle on 30 October. After the continued defeats of the Armenian army, the Armenian government accepted Turkish conditions and signed the Gumru treaty that set the actual borders between Turkey and Armenia thus surrendering Kars to Turkey. Consequently, Karabekir was awarded the title of Conqueror of the East, a position that fuelled his rivalry with Mustafa Kemal. ${ }^{67}$ Patrick Kinross states that the Armenian army retreating from Kars was 'followed in a panic by droves of civilians dreading, not wholly without reason, rape and robbery and massacre at the hands of the Turks'. ${ }^{68}$ Snow expresses a subtle irony with respect to the Turkish victory in Kars by representing the Kazim Karabekir statue as 'a giant ice-cream

\footnotetext{
${ }^{66}$ In 1915, the CUP (or Committee for Union and Progress) leadership, which was in power in the Ottoman state, formally accused Armenians of betraying the Ottoman state through cooperation with Russia and the Allies. They ordered the deportation of Armenians to Syria and Iraq.

There is a huge number of works on the Armenian massacres that accompanied the series of deportations, and their possible genocidal dimensions. Some of the best researched and most influential recent scholarly studies on the historical, political, and sociological complexities of this issue are: Taner Akcam, From Empire to Republic: Turkish Nationalism and the Armenian Genocide (London: Zed Books, 2004) and A Shameful Act: The Armenian Genocide and the Question of Turkish Responsibility (New York, NY: Metropolitan Books, 2006); Vahakn N. Dadrian, The History of the Armenian Genocide: Ethnic Conflict from the Balkans to Anatolia to the Caucasus (4th rev. edn) (Oxford: Berghahn, 2003); and Peter Balakian, The Burning Tigris: The Armenian Genocide and America's Response (New York, NY: HarperCollins, 2003). Other works include Katia Minas Peltekian, Heralding of the Armenian Genocide: Reports in the Halifax Herald 1894-1922 (Halifax, NS: Armenian Cultural Association of the Atlantic Provinces, 2000); Donald E. Miller and Lorna Touryan Miller, Survivors: An Oral History of the Armenian Genocide (Berkeley, CA: University of California Press, 1993); and Christopher de Bellaigue, Rebel Land: Among Turkey's Forgotten Peoples (London: Bloomsbury, 2009). Interestingly, Ka's journey into Kars can be compared in some ways to Bellaigue's personal exploration of Varto in eastern Turkey as he attempts to unravel the silence enveloping the history of the massacres of Armenians and of the Turkish-Kurdish conflict by interviewing - while being followed by plainclothes policemen — a variety of people including a mistrustful mayor, a Turkish army captain, members of the PKK, and descendants of Armenian survivors of the massacres.

${ }^{67}$ Mango, Ataturk, pp. 293-295.

${ }^{68}$ Patrick Kinross, Ataturk: The Rebirth of a Nation (London: Phoenix, 1995), p. 244.
} 
cone' ${ }^{69}$ While it buries the Karabekir statue in a silent snow-covered landscape, Pamuk's novel unearths the signs of past Armenian presence in Kars and unravels sites of past tragedies which have been buried in whitewashed silence. Bleak yet illuminating moments in the narrative include instances as when ' $\mathrm{Ka}$ passes an empty one-story Armenian house, its windows boarded up' ${ }^{70}$ Near the end of the novel, Orhan, the narrator and Pamuk's namesake in Snow, meets an Islamist party ex-candidate who makes a summary judgement on the destruction of a 100-yearold building: 'At least it was an Armenian building and not a Turkish one' ${ }^{71}$ The haunting presence of Armenian architectural remains marks the textual space of Snow with an insistence that critically memorialises these non-monumental sites. ${ }^{72}$ As such, the narrative performs its own commemoration of the Armenian tragedy in Kars thus enacting what Ricoeur specifies as 'the duty to do justice, through memories, to an other than the self' ${ }^{73}$ It is the equivalent of the process of 'active remembering' which Akcam, among others, considers as Turkey's duty towards a chapter of its past 'in the face of forgetting, ignoring, and repressing' ${ }^{74}$

Near the beginning of Snow, Ka meets his lover Ipek in a pastry shop which 'had been an Orthodox church until 1967, when the door had been removed and taken away to the museum. A section of the same museum commemorated the Armenian Massacre (naturally, she said, some tourists came expecting to see remnants of the Turks' massacre of the Armenians, and it was always a jolt to discover that in this museum the story was the other way around)'. ${ }^{75}$ These lines reveal the dissemination of the meaning of the 'Armenian Massacre' amid a conflict between two extremely opposed viewpoints that have produced contradictory readings of past atrocities. Analysing Turkish society's defence mechanisms in relation to the tabooed subject of the Armenian massacres, Akcam argues that: 'The primary defense mechanisms that Turks use regarding their history are denying those things that were experienced, marginalizing them and behaving as if they never occurred, and projecting their deeds and claiming that "we Turks did not murder Armenians; Armenians murdered us", 76 The parenthetical comment in Pamuk's text implicitly hints at such processes of denial, marginalisation, and projection without reducing the interpretive conflict to a straightforward psychological or political reading. Pamuk thus presents the museum as a contested space wherein the Turkish discourse on the Armenian massacres competes with the meanings that the tourists bring to it. At the same time, these lines subtly extend the political and historical critique by hinting at the loss of Turkish lives during the campaign on Kars.

\footnotetext{
${ }^{69}$ Pamuk, Snow, p. 68.

${ }^{70}$ Pamuk, Snow, p. 163.

${ }^{71}$ Pamuk, Snow, p. 412.

72 The references to Armenian houses, mansions, government buildings, and other architectural sites previously occupied by Armenians occur, in Snow, on pages 9, 11, 20, 132, 163, 164, 166, 180, 412, 416, 422, 424. The documentary work, The Armenians Remember, discusses 'the massacres of the monuments of art' whereby an 'invaluable [Armenian] archeological heritage was lost from Kars'. Armenian Information Center in Beirut, The Armenians Remember... 1915: Fiftieth Commemoration of a Genocide (Beirut: Armenian Information Center, 1965), p. 43.

${ }^{73}$ Ricoeur, Memory, p. 89.

${ }^{74}$ Akcam, From Empire to Republic, p. 217. See Chapter 7 'The Causes and Effects of Making Turkish History Taboo', pp. 208-225.

${ }_{75}^{75}$ Pamuk, Snow, p. 33.

${ }^{76}$ Akcam, From Empire to Republic, p. 211.
} 
The body of Pamuk's Snow communicates the traumatic taboo and the tabooed trauma of the Armenian massacres which still haunt Turkish and Armenian lived spaces, historical debates, and political milieus. Pamuk's narrative thus performs the paradoxical double act of memory/justice and forgiveness. This is the 'therapeutic' double act that Ricoeur emphasises when he concludes his reflection on the relations of memory, history, and amnesty in relation to past atrocities including genocidal acts: 'Political prose begins where vengeance ceases, if history is not to remain locked up within a deadly oscillation between hatred and forgetful memory'. ${ }^{77}$ The political and historiographical conflicts over the traumatic and tabooed episode of the Armenian massacres and their genocidal dimensions have often been caught in the grips of the equally dangerous powers of hatred and forgetful memory. Recent scholarly work on the massacres has attempted to find discursive ways out of this conflict. ${ }^{78}$ By imaginatively revisiting a history of violence and mediating alternative forms of monumentalisation with respect to this history, Pamuk's Snow contributes to this attempt by suggesting political possibilities beyond hatred, that often causes or results from terror, and forgetful memory, that is frequently a symptom of taboo.

In one of the essays of Other Colours, his recently published collection of writings, Pamuk states:

In a cobbled-together demi-democracy like ours, in this society so riddled with prohibitions, writing novels puts me in a position not altogether different from my traditional storyteller's; and whatever the explicit political prohibitions might be, a writer will also find himself hemmed in by taboos, family relations, religious injunctions, the state, and much else. ${ }^{79}$

Pamuk's statement is a general yet most adroit description of some of the constraints that The Black Book and Snow astutely tackle and unravel. As this essay has shown, Pamuk's novelistic ventures into the delicate and vital issues that mark contemporary Turkish politics trace a trajectory between, and beyond, terror and taboo. These imaginative journeys occur across the matrix of monumental space and the various acts and meanings of monumentalisation. In The Black Book and Snow, monumentalisation does not simply refer to an object that is viewed or ignored, built and destroyed, brought to spatial and discursive prominence or mentally erased due to excessive familiarity and redundance in the urban fabric. It also refers to the phenomenon of monumentalisation as articulated in the Ataturk cult and its accompanying monument-making project that marked both the birth of the Turkish Republic and the moments in which Kemalist ideology considered itself in danger. More significantly, in The Black Book and Snow, monumentalisation is an act which the text performs or to which it reacts in several ways: by unravelling traces of repression or terror in the tabooed Turkish monumental space and history; by weaving democratic theatrics and carnivalesque ambivalence in the space of an Ataturk statue; by underlining the interplay of terror and taboo in Kurds' real or imagined attacks against Ataturk statues and the state's violent reactions to these; and by giving monumental significance in the text to spaces marked by traces of past violence against Armenians. These textual performances ingeniously refract the historical nexus of

\footnotetext{
${ }_{77}^{7}$ Ricoeur, Memory, pp. 500-501.

78 See footnote 66.

79 Orhan Pamuk, 'A Selection from Interviews on My Name is Red', in Pamuk (ed.), Other Colours, p. 263.
} 
terror and taboo onto the body of the two novels by means of the surreal and apocalyptic image, the textual marginalisation of the tabooed figure or the tabooed act, and the textual foregrounding of the ephemeral evidence of past terror.

Accordingly, this essay has demonstrated that Pamuk's The Black Book and Snow enable a critical and ethical engagement with the politics of monumentalisation and its relations to terror and taboo in twentieth-century Turkey and with monumentalisation as an idea, and an act whose political significance emerges not merely when it is materially realised on the ground but also, and more importantly, when it is thought, reimagined, and redefined in the literary text and the critical response to it. 